\title{
Pengaruh Tahfidz Metode Talaqqi Online terhadap Pengenalan Hijaiyah TK Program Tahfidz Sleman
}

\author{
Shin Prathiwi ${ }^{\circledR}$, Amir Syamsudin ${ }^{\circledR}$ \\ Pendidikan Anak Usia Dini, Universitas Negeri Yogyakarta ${ }^{(1,2)}$ \\ DOI: $10.31004 /$ obsesi.v6i1.1232
}

\begin{abstract}
Abstrak
Program tahfidz semakin marak dilakukan secara implisit atau eksplisit pada kurikulum TK. Penelitian dilaksanakan dengan tujuan menguji pengaruh kemampuan tahfidz metode talaqqi online $(x)$ terhadap pengenalan huruf hijaiyah $(y)$ pada anak TK program tahfidz. Penelitian ini menggunakan metode kuantitatif expost facto untuk mengungkap kondisi lapangan. Penelitian memperoleh hasil, diketahui pengaruh yang bermakna antara kemampuan tahfidz terhadap mengenal huruf hijaiyah. Teknik pengambilan data yang digunakan yaitu lembar tes dan observasi oleh guru. Teknik analisis pada penelitian ini memakai analisis SEM-PLS. Analisis dipilih disebabkan jenis data bersifat ordinal. Pengisian lembar tes dan observasi diwakili oleh guru berdasarkan jawaban anak, dikarenakan pengambilan data dilakukan secara online terdampak covid-19. Kebaruan penelitian ini yaitu metode tahfidz menggunakan talaqqi online. Metode talaqqi online mendukung pelaksanaan kegiatan tahfidz dan pengenalan huruf hijaiyah anak.
\end{abstract}

Kata Kunci: pengenalan huruf hijaiyah; program tahfidz; kognitif anak usia dini.

\begin{abstract}
Hifz (memorization of the Quran) program increasingly become usual on the preschool educational curriculum either implicitly or explicitly. This research aims to examine online talaqqi $(x)$ affects toward Hija'i Arabic alphabet recognition $(y)$ for kindergarten student which take Hifz program. In order to denote the real condition, expost facto quantitative method used in this research. The result satisfied the effect of online talaqqi toward Hija'i Arabic alphabet recognition. The data retrieval method using assessment sheet and observation by teacher. Analysis technique using SEM-PLS due to ordinal data type retrieved on preceding method. Both assessment sheet filling and observation are mandated to the teacher based on students answer due to covid-19 impact as of online data retrieval. The novelty is Hifz using online talaqqi. The online talaqqi supports implementation of Hifz and Hija'i Arabic alphabet recognition for kindergarten.
\end{abstract}

Keywords: hija'i arabic alphabet recognition; hifz program; early childhood cognitive.

Copyright (c) 2021 Shin Prathiwi, Amir Syamsudin

$\triangle$ Corresponding author :

Email Address : zhin.chie@gmail.com [Semarang, Indonesia]

Received 28 March 2021, Accepted 1 April 2021, Published 7 April 2021 


\section{PENDAHULUAN}

Program tahfidz sudah banyak diselenggarakan mulai jenjang TK. Program tahfidz dilaksanakan secara implisit dan eksplisit dalam kurikulum sekolah islam. Tiap tahun TK muatan islam selalu mengalami peningkatan 2,30\% (Prathiwi \& Syamsudin, 2020). Padahal anak yang menempuh program tahfidz mempunyai capaian yang berbeda dibandingkan anak program pendidikan pada umumnya. Anak program tahfidz di TK diwajibkan mempelajari Qur'an lebih dini sebagai sumber ilmu pertama dan utama (Wahyuni \& Syahid, 2019) sehingga capaian bidang kognitif mereka bertambah dari mengenal huruf hijaiyah dan menghafalkan surat dengan metode tertentu (Susianti, 2016).

Huruf hijaiyah mempunyai proses pengenalan huruf yang sama dengan huruf lain. Beberapa huruf hijaiyah memiliki bentuk dan pengucapan yang mirip akan tetapi sebenarnya berbeda. Huruf hijaiyah adalah 29 huruf alfabet yang digunakan dalam bahasa Arab, kitab Qur'an, hadist dan sholat (Halimah, Fadillah, \& Ali, 2015; Mashuri \& Dewi, 2017). Pengenalan huruf hijaiyah anak usia dini pada tahap awal dilakukan pengenalan bunyi, bentuk dan harakat yang berbeda antar huruf (Widyawanti, 2016). Pengenalan huruf hijaiyah dilakukan dengan anak mengeja huruf dan harakat satu persatu (Nurhayati, 2019; Rifaatin, 2018). Perbedaan antar huruf hijaiyah sering membingungkan anak.

Hal ini karena beberapa huruf memiliki bentuk dan bunyi yang mirip (Vermala, Puspitaningrum, \& Setiawan, 2016). Kondisi ini diperburuk bila anak tidak hafal urutan huruf hijaiyah (Sari, Fadillah, \& Lukmanulhakim, 2017) dan pergantian harakat dasar ( $\underset{-}{-}$ ) (Khadijah, 2019). Kebingungan identifikasi disebabkan beberapa huruf memiliki bentuk mirip dan perbedaan huruf hanya ditandai oleh letak titik atau garis ganda pada harakat. Kecermatan diperlukan anak saat proses pengenalan huruf hijaiyah.

Anak pada usia tertentu sudah mampu mengucapkan huruf hijaiyah. Anak usia 5 - 6 tahun di Arab Saudi, mampu mengenal dan mengucapkan 29 huruf hijaiyah (Amayreh \& Dyson, 1998). Anak memerlukan dukungan orang dewasa untuk mengenal dan memperdalam huruf hijaiyah (Amayreh \& Dyson, 1998; Grigorenko, 2009). Hanya 10 huruf hijaiyah homofon yang dilatihkan secara intens pada anak usia 5-6 tahun, huruf tersebut

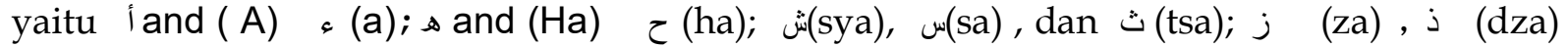
dan ج (ja)(Marlina et al., 2018). Dukungan orang dewasa dibutuhkan anak dalam mengenal huruf hijaiyah karena memudahkan anak merasakan karakter dan penggunaan huruf hijaiyah. Dukungan dapat diberikan berdasarkan kompetensi huruf per-usia anak.

Anak pada kelompok B program tahfidz berada dalam rentang usia 5-7 tahun atau tahap praoperasional. Anak praoperasional masih memiliki keterbatasan pemusatan perhatian dan nalar (Patterson, 2008 : 282). Keterbatasan ditunjukan saat anak belum mampu memahami perubahan susunan suatu objek, yang tidak terdapat perubahan jumlah (properti) (Patterson, 2008; Papalia, Olds, \& Feldman, 2009). Meskipun anak masih terbatas dalam aspek penalaran, memori anak masa praoperasional sudah dapat digunakan dengan baik.

Mereka memperoleh metode talaqqi sebagai dukungan (scaffolding) dalam melafalakan huruf hijaiyah dan menghafalkan surat untuk meringankan tambahan pencapaian perkembangan kognitif. Hal tersebut sejalan dengan teori Vygotsky. Pendekatan konstruktivisme sosial menyatakan pengetahuan adalah hasil belajar dari interaksi sosial yang terjadi pula pada anak dan orang dewasa (Papalia, Olds, \& Feldman, 2009 ; Lourenço, 2012). Pembentukan konsep pada teori konstruktivisme sosial, melalui proses belajar atau penerimaan yang melibatkan orang lain selama kegiatan menambah pengetahuan berlangsung (van Compernolle \& Williams, 2013). Konsep ini menunjukan dukungan lingkungan dapat pula berupa ketersediaan bahan sumber pengetahuan. Tetapi ketersediaan sumber belajar tanpa bimbingan, hanya akan menghasilkan pengetahuan dari satu persepsi. Sumber pengetahuan dengan bimbingan orang dewasa akan menghasilkan pengetahuan lebih beragam (konstruk) yang diterima anak saat interaksi (sosial) terjalin. 
Teori konstruktivisme sosial juga beroperasi dengan melibatkan banyak komponen. Selain keterlibatan orang lain, budaya lokal juga turut mempengaruhi proses belajar anak karena informasi dan budaya masuk secara bersamaan ketika anak belajar (Konzulin, 2003; Utami, 2016; Santrock, 2018). Namun, partisipasi aktif individu juga dibutuhkan dalam mengkonstruksi pengetahuan sehingga anak tetap berkreasi, memaknai, memilih dan menyebarkan kembali informasi yang dimilikinya (Budiningsih, 2003; Lourenco, 2012). Teori konstruktivisme sosial menekankan pengaruh interaksi sosial manusia yang kaya berbagai komponen berguna untuk membentuk pengalaman, pengetahuan dan penalaran yang tidak bisa dilakukan sendiri. Kondisi ini tercermin pula pada anak TK program tahfidz.

Anak TK program tahfidz memiliki tambahan capaian yang sengaja dibentuk oleh lingkungan. Tambahan capaian berdampak beban kompetensi yang lebih banyak pada area perkembangan kognitif anak TK program tahfidz. Capaian tersebut konon sudah disesuaikan dengan perkembangan anak dan dengan bimbingan ahli. Hal ini sesuai dengan teori pembelajaran konstruktivisme sosial yang menggunakan ZPD untuk meraba perkembangan anak dan scaffolding sebagai bimbingan. Zona proximal development (ZPD) merupakan area antara perkembangan aktual dan perkembangan maksimal (Santrock, 2018: 50). ZPD berfokus pada pengajaran dan pembelajaran yang merintis perkembangan anak, bukan sekedar mengikuti perkembangan yang tampak dimiliki anak (aktual) (Vygotsky, 1978). Capaian anak TK program tahfidz tentu membutuhkan ZPD karena tuntutan kompetensi menghafalkan surat yang tidak sebanding dengan kompetensi kognitif TK pada umumnya. Selain itu, dukungan diberikan sebagai penyeimbang antar tugas perkembangan kognitif karena tugas kognitif anak pada umumnya sudah beragam.

Tugas perkembangan kognitif anak periode praoperasional usia 5-7 tahun mencakup pengenalan simbol. Disisi yang bersamaan anak memperoleh materi pengenalan huruf hijaiyah (y) melalui penerapan kurikulum nasional di sekolah. Hasil penelitian juga menyatakan bahwa anak usia 5 hingga 6 tahun sudah memiliki kemampuan mengenal seluruh huruf hijaiyah (Amayreh \& Dyson, 1998). Pada sekolah program tahfidz, simbol yang dikenalkan kepada anak lebih beragam dan terdapat capaian tambahan yaitu keterampilan mengidentifikasi huruf dan menghafalkan Qur'an. Padahal huruf hijaiyah merupakan huruf dari bahasa Arab yang hanya digunakan saat beribadah dan berdoa (Susianti, 2016).

Anak menerima pengenalan huruf hijaiyah dan penghafalan surat pendek metode talaqqi pada juz 30 secara bersama-sama. Tugas perkembangan kognitif menjadi lebih beragam pada anak program tahfidz dan menghafalkan surat pada juz 30 belum menjadi kompetensi resmi untuk anak TK. Meskipun demikian anak menerima dukungan pembelajaran dengan penggunaan metode talaqqi dalam pelaksanaan program tahfidz. Talaqqi musyafahah atau talaqqi merupakan metode pertama yang digunakan menghafalkan Al-qur'an. Metode ini dinilai tepat untuk anak karena pelaksanaan sesuai perkembangan anak yang terbatas dalam bacatulis. Penerapan talaqqi memerlukan keterlibatan orang dewasa untuk menyempurnakan dan menjaga hafalan hufazh. Metode talaqqi (talaqqi musyafahah) digunakan oleh Jibril untuk mengajarkan dan menghafalkan Al-qur'an kepada Rasulullah Muhammad SAW yang saat itu dalam kondisi buta huruf (Ariffin, Abdullah, \& Ahmad, 2015; Hasan et al., 2017). Talaqqi adalah metode menghafal Qur'an yang memerlukan bimbingan orang dewasa (ustadz/dzah atau orang berilmu) dengan bertatap muka langsung dalam pelaksanaan pada anak (Ahmad, 2002 ; Hurriyati, Fitriana, Cahyadi, \& Srisayekti, 2017; Mohed \& Ismail, 2015; Nurwahyudi, 2018).

Akan tetapi pandemi covid-19 membatasi pelaksanaan kegiatan tahfidz dengan metode talaqqi di sekolah. Untuk tetap mendukung terlaksana kegiatan tahfidz, pihak sekolah menerapkan program tahfidz dengan metode talaqqi online. Sebagaimana program talaqqi pada umumnya, talaqqi online mempermudah anak bertatap muka melalui aplikasi penyedia video call. Dengan tatap muka virtual tersebut, kegiatan tahfidz anak tetap berjalan. Program tahfidz ini tetap membutuhkan ketekunan dan intensitas pengulangan agar memori surat tetap 
tersimpan. Pada kondisi bersamaan memori juga digunakan konsep pengenalan huruf hijaiyah.

Penelitian serupa, pernah dilakukan untuk mengamati pelaksanaan program tahfidz di TK. Penelitian program tahfidz pada anak kelompok B menunjukan hasil bahwa program tahfidz dan pelafalan huruf hijiayah berpengaruh positif terhadap kamus surat anak (Nastiti, 2015). Surat dan metode yang digunakan untuk mengukur penelitian tersebut yakni Surat AlInsyirah dan talaqqi (Faiziyah, 2018; Nastiti, 2015). Pada kondisi dilapangan anak TK Kelompok B memiliki capaian melampaui surat tersebut. Sehubungan dengan kondisi tersebut, anak program tahfidz juga diberikan materi huruf hijaiyah sebagai pengetahuan dasar untuk membantu kesempurnaan hafalan mereka ( Marlina et al., 2018; Nastiti, 2015; Susianti, 2016).

Pengukuran ini mengadaptasi penelitian relevan terdahulu guna mengamati topik. Kondisi dilapangan menunjukan program tahfidz saat ini telah diselenggrakan mulai jenjang Taman Kanak-kanak (TK). Penelitian ini menguji pengaruh kemampuan tahfidz metode talaqqi $(x)$ terhadap pengenalan huruf hijaiyah $(y)$ pada TK Program Tahfidz di Sleman Provinsi Daerah Istimewa Yogyakarta.

\section{METODOLOGI}

Metode penelitian yang digunakan dalam penelitian ini, adalah kuantitatif expost facto. Metode tersebut dipilih karena tidak memungkinkannya dilakukan penelitian yang menjadikan program tahfidz sebagai rekayasa kondisi atau manipulasi variabel (penelitian eksperimen). Dari keterbatasan tersebut, maka pengamatan dan pengukuran menggunakan kondisi alami dari objek, yaitu TK program tahfidz. Hal ini disebabkan sulit menciptakan kondisi rekayasa dan sulit mentindak lanjuti atas kondisi rekayasa yang terbentuk. Penelitian ini dilaksanakan pada 3 TK Program Tahfidz Metode Talaqqi Juz 30 di Sleman - DIY. Sejumlah 56 anak usia 5-6 tahun (Kelompok B) terlibat dalam penelitian ini. Pengukuran dilakukan menggunakan lembar tes yang ditampilkan secara online pada anak dihari pengambilan data. Data penelitian ini berjenis ordinal. Sebelum diujikan pada anak, lembar tes telah melalui uji validitas dan reliabilitas sejumlah 13 expert judgment. Dari pengujian tersebut, diketahui seluruh butir instrumen memiliki skor diatas ambang uji validitas $(0,69)$ dan reliabilitas $(0,74)$ of ratings. Hasil uji validitas dan reliabilitas of ratings tersaji pada Tabel 1.

Tabel 1. Uji Validitas dan Reliabilitas of Ratings Kemampuan Tahfidz (KT/ $x$ ) terhadap Huruf Hijaiyah (HH/ y)

\begin{tabular}{lcccc}
\hline $\begin{array}{c}\text { 13 Expert } \\
\text { Judgment }\end{array}$ & KT1 & KT2 & HH1 & HH2 \\
\hline Validitas & 0,718 & 0,718 & 0,744 & 0,72 \\
\hline Reliabilitas & 5,462 & 5,462 & 5,692 & 5,46 \\
\hline
\end{tabular}

Terdapat 4 butir soal yang diujikan. Pertama, anak akan diminta untuk menyebutkan 29 huruf hijiayah (HH1). Jika anak mengucapkan huruf hijaiyah $>7$, maka anak mendapat skor 1. Sedangkan jika anak menyebutkan 22-29 huruf hijiayah, maka anak memperoleh skor 4. Kedua, anak diuji menyebutkan 5 huruf hijaiyah yang homofon (HH2). Anak mengucapkan secara fasih dan menunjukkan istilah $<2$ huruf hijaiyah homofon, maka mendapat skor 1 . Tetapi jika mampu mengucapkan 5 huruf hijiayah homofon, maka mendapat skor 4.Ketiga, pengukuran surat yang menjadi capaian saat pengukuran (KT1). Anak mendapat skor 1 bila mengingat hanya 1-2 ayat Q.S. At-Takasur. Akan tetapi anak memperoleh skor 4 apabila menghafal 7-8 ayat. Terakhir, pengujian kamus surat pada 4 surat pendek (KT2). Anak mendapat skor 1 bila mengingat hanya 1 surat pendek dari surat An-Naas, Al-Lahab, Al-Maun atau Al-Humazah. Namun anak memperoleh skor 4 apabila menghafal seluruh surat pendek. 
Setelah melalui uji validitas dan reliailitas, lembar tes diserahkan dan diisi oleh guru dengan menyesuaikan jawaban anak saat dilakukan pengukuran. Pengukuran anak dilakukan dalam 1 kali tes. Penilaian hasil jawaban anak, dibagi dalam 4 skala. Skala 1 terendah dan skala 4 tertinggi. Pengukuran dalam penelitian ini, berkolaborasi dengan guru dan peneliti sebagai observer. Kemudian data anak dianalisis menggunakan structural equation model partial least square (SEM-PLS). SEM-PLS ditetapkan sebagai analisis data anak dikarenakan jenis data penelitian yang bersifat ordinal dan berjumlah kecil. Lebih lanjut mengenai analisis SEM-PLS yang digunakan, tersaji pada gambar 1.

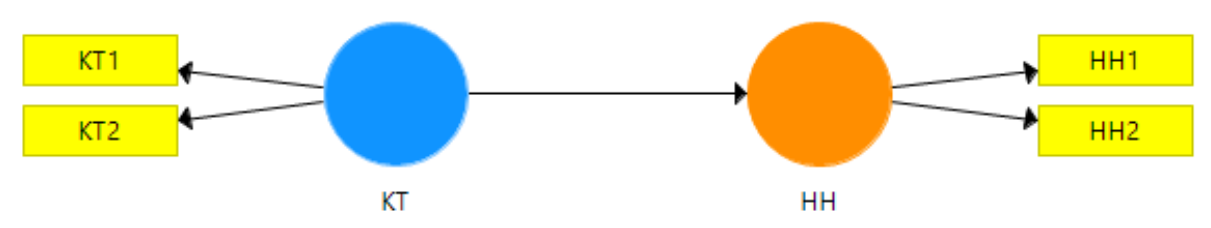

Gambar 1. Skema Analisis SEM Kemampuan Tahfidz (KT/ $x$ ) terhadap Huruf Hijaiyah (HH/ y)

\section{HASIL DAN PEMBAHASAN}

Anak Tk Tahfidz menerima materi agama dan materi umum pada hari yang sama. Begitu pula pada hasil observasi lapangan penelitian ini. Anak merima materi pengenalan huruf hijaiyah dan tahfidz pada hari yang sama. Padahal waktu belajar anak usia 5-6 tahun ini masih terbatas 6 jam (sekolah offline) dan 1,5 jam (sekolah online). Waktu yang terbatas dan capaian yang lebih beragam menunjukan pengaruh kepada anak. Pembahasan lebih mendalam tentang pengaruh terkait topik, hasil pengambilan data dan pengolahan, akan dijelaskan pada gambar 2 .

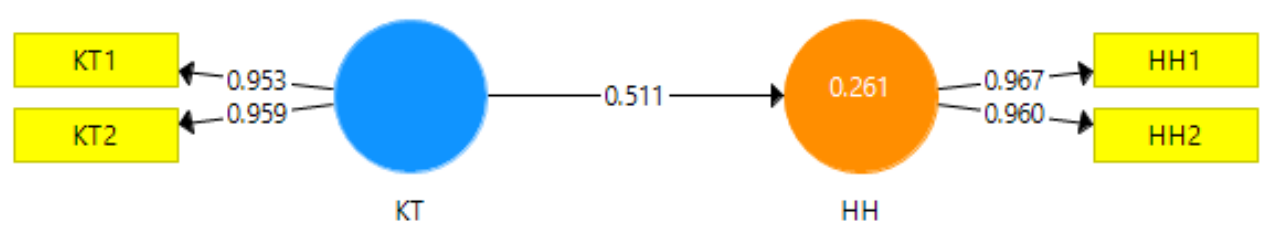

\section{Gambar 2. Hasil Uji Pengaruh KT terhadap HH}

TK Program Tahfidz pada anak di Lapangan, menggunakan indera pendengaran sebagai sarana utama dalam menghafalkan surat pendek. Cara menghafalkan pada anak dilakukan dengan mendengarkan terus-menerus rekaman, lantunan orang tua dan lantunan guru. Metode ini sesuai dengan metode talaqqi. Kondisi sangat mencitrakan talaqqi, dimana anak menggunakan pendengaran dan pengucapan secara berulang (Ikhwanuddin, 2007; Susianti, 2016). Anak didengarkan surat pendek Juz 30 secara rutin karena keterbatasan mereka dalam kemampuan membaca yang kompleks.

Capaian surat yang dihafalkan pada TK Program Tahfidz, juga dibatasi hanya Juz-30. Hal ini disebabkan kemampuan pelafalan anak masih terbatas dan intensitas pengulangan dalam sholat yang sering dilakukan. Sesuai dengan konsep yang menjelaskan, Juz 30 dipilih sebagai Juz hafalan anak usia dini karena berisikan surat pendek yang diguakan untuk sholat (Susianti, 2016). Pelaksanaan program tahfidz pada anak, ditemukan telah menggunakan pendekatan konstruktivisme sosial. Penggunaan teori konstruksitivisme sosial, nampak dari anak dapat menghafalkan surat pendek pada juz 30 dengan bantuan rekaman, guru dan orang tua mereka.

Hal ini sangat sejalan dengan teori konstruktivisme sosial, dimana anak perlu keterlibatan orang lain saat menerima informasi baru (Vygotsky, 1978). Meskipun demikian, tetap perlu partisipasi aktif anak yang ditandai dapat memahami dan menyebarkan kembali 
(Budiningsih, 2003; Lourenco, 2012). Kondisi pada Anak program tahfidz cenderung lebih pasif karena anak masih kesulitan untuk mengingat kembali surat yang dahulu sudah dihafalkan.

Kondisi kesulitan mengingat kembali surat yang dahulu dihafalkan, diprediksi karena anak usia Kelompok B, masih memiliki keterbatasan konsentrasi dan perhatian. Seperti teori yang menyatakan bahwa anak usia 5-6 tahun, mempunyai keterbatasan perhatian sehingga menyebabkan perhatian mudah terpecah (Patterson, 2008 : 282).

Beberapa kondisi materi tahfidz pada anak TK Program Tahfidz yang telah dijabarkan sebelumya, didapatkan data pengukuran yang diobservasi oleh guru. Kondisi kemampuan tahfidz yang muncul pada anak, mempunyai nilai konversi sesuai kemampuan masing-masing anak. Nilai konversi tersebut merupakan sumber untuk pengujian yang telah dilakukan.

Hasil Gambar 2, tampak pengaruh variabel kemampuan tahfidz $(x)$ terhadap pengenalan hijaiyah (y). Pada Gambar 2 membuktikan bahwa tahfidz ( $x$ ) metode talaqqi memiliki pengaruh terhadap pengenalan hijaiyah (y). Hal ini terlihat dari skor hitung kemampuan tahfidz $(x)$ pada uji pengaruh sebesar $(+) 0,511$. Hasil tersebut sejalan dengan penelitian dari Safitri. Dengan mendengarkan dan menyimak surat, anak terlatih membedakan huruf hijaiyah (Safitri, 2011). Kondisi di Lapangan menunjukan variabel tahfidz $(x)$ memiliki arah pengaruh negatif " + " terhadap pengenalan huruf hijaiyah (dari hasil Tabel $14)$.

Arah positif dapat diasumsikan bahwa kemampuan tahfidz $(x)$ mendukung pengenalan huruf hijaiyah anak sebesar 0,511 atau $51,10 \%$. Hasil tersebut semakin sejalan dengan penelitian Safitri. Pada kondisi lapangan, anak mengalami kesulitan dalam menghafalkan intermezo (surat pendek). Justru tidak mengalami kesulitan mengenal huruf hijaiyah, meskipun mereka sebelumnya diminta untuk menghafalkan beberapa surat pendek. Kondisi ini seperti konsep yang menyatakan kecepatan pemanggilan ingatan bergantung pada intensitas pengulangan (Schacter \& Addis, 2007;). Hal ini menimbulkan prediksi telah terjadi ketimpangan pengulangan antara materi tahfidz dan pengenalan huruf hijaiyah pada anak. Lebih lanjut jika ditelaah berdasarkan konsep lain, pengalaman tentang sebuah informasi yang telah dilalui dapat tersimpan dengan kurun waktu tertentu menyesuaikan intensitas pengulangan (King, 2013: 217). Kecuali terjadi kesenjangan kondisi scaffolding antara orang tua dan guru mempengaruhi proses hafalan surat pendek Juz 30 anak (Ermawati, 2009).

Akan tetapi pengukuran mengenai intensitas pengulangan surat-surat terdahulu (selain At-Takassur) pada anak dan kesenjangan perlakuan orang tua, sudah diluar batas penelitian ini. Merujuk pada salah satu teori, menyebutkan faktor yang sangat berpengaruh dalam proses menghafalkan adalah konsentrasi dan lingkungan terkondisikan (Ikhwanuddin, 2007). Rangkaian teori tersebut, menjadi dapat dipertimbangkan karena pembelajaran anak terdampak pandemi covid-19. Dengan demikian hasil olah analisis SEM PLS menunjukan kemampuan tahfidz $(x)$ berpengaruh positif sebesar 0,511 terhadap pengenalan huruf hijaiyah anak usia 5-6 tahun. Atau dengan kata lain, pengenalan kemampuan tahfidz $(x)$ meningkatkan secara signifikan terhadap pengenalan huruf hijiayah anak.

\section{SIMPULAN}

Metode talaqqi online merupakan alternatif untuk digunakan pada kegiatan tahfidz anak selama masa pandemi covid-19. Sebagaimana metode talaqqi pada umumnya, talaqqi online hanya memerlukan perhatian saat mendengarkan dan mengulang ayat kembali secara online sehingga anak tidak diharuskan dapat membaca. Dari pengukuran yang telah dilakukan, diperoleh simpulan bahwa kemampuan tahfidz metode talaqqi online mempengaruhi secara bermakna terhadap pengenalan huruf hijaiyah anak usia 5- 6 tahun. Dengan demikian menjadi bukti bahwa kemampuan tahfidz dengan metode talaqqi mempermudah anak dalam pengenalan huruf hijaiyah. 


\section{UCAPAN TERIMA KASIH}

Penulis menyampaikan terima kasih kepada berbagai pihak yang berpartisipasi dalam pelaksanaan penelitian ini. Lebih lanjut penulis mengucapkan terimakasih kepada Yayasan TK BIAS dan TK AnaQu wilayah Sleman, yang telah memberikan ijin penyelenggaraan penelitian. Ucapan terimakasih juga penulis sampaikan untuk Universitas Negeri Yogyakarta, yang memberi kesempatan penyusunan penelitian ini.

\section{DAFTAR PUSTAKA}

Ahmad, M. Y. (2002). Falsafah dan sejarah pendidikan islam. Kuala Lumpur: University Malaya.

Amayreh, M. M., \& Dyson, A. T. (1998). The acquisition of arabic consonants. Journal Speech, Language And Hearing Research, 41, 642-653. https://doi.org/10.1044/jslhr.4103.642

Ariffin, S., Abdullah, M., \& Ahmad, K. (2015). Module Of Al-Quran Memorization According To Capability And Period. Agama, Linguistik Dan Pendidikan, 83, 82-90.

Ermawati, E. (2009). Metode Pembelajaran Tahfiz Juz "Amma di Taman Kanak-Kanak Islam Terpadu ( Tkit ) Imam Syafi"I Yogyakarta. Universitas Ilsam Negeri Sunan Kalijaga Yogyakarta.

Faiziyah, N. (2018). Memorizing Qur'an and Mathematics Achievement Nuqthy. Mathematics Education Journals, 2(1), 7-11. https://doi.org/10.22219/mej.v2i1.5800

Grigorenko, E. L. (2009). Multicultural psychoeducational assessment. New York: Springer Publishing Company.

Halimah, Fadillah, \& Ali, M. (2015). Peningkatan pengenalan huruf hijaiyah melalui metode bernyanyi pada anak usia 5-6 tahun. Jurnal Pendidikan Dan Pembelajaran, 5(5).

Hasan, A. R. A., Ghani, A. R. A., Jemali, M., Nasir, N. F. W. M., Yusuf, M. Y. M., \& Ariffin, M. F. M. (2017). Learning Concepts and Educational Development of Hafazan Al-Quran in the Early Islamic Century. International Journal of Academic Research in Business and Social Sciences, 7(10), 628-636. https://doi.org/10.6007/IJARBSS/v7-i10/3417

Hurriyati, E. A., Fitriana, E., Cahyadi, S., \& Srisayekti, W. (2017). Phonological Loop Phenomena On Qur'an Reciters "Baddeley's Model Of Verbal Working Memory." In Proceeding International Conference On Islamic Education (Icied) "Innovations, Approaches, Challenges, And The Future" (pp. 113-123).

Ikhwanuddin, M. (2007). Relationship between memorization technique, mastery of The Arabic Language and understanding of The Qur'an. Tasyri', 24(1), 1-13. https://doi.org/10.31436/ijes.v2i2.46

King, L. A. (2013). The science of psychology: An appreciative view. Boston: McGraw-Hill Higher Education.

Khadijah. (2019). Analisis kesulitan anak dalam membaca huruf hijaiyyah berdasarkan pandangan matematis. Jurnal Ilmiah Pendidikan Matematika, 2(1), 42-52.

Lourenço, O. (2012). New Ideas in Psychology Piaget and Vygotsky : Many resemblances, and a crucial difference. New Ideas in Psychology, 30(3), 281-295. https://doi.org/10.1016/j.newideapsych.2011.12.006

Marlina, L., Wardoyo, C., Sanjaya, W. S. M., Anggraeni, D., Dewi, S. F., Roziqin, A., \& Maryanti, S. (2018). Makhraj recognition of Hijaiyah letter for children based on MelFrequency Cepstrum Coefficients (MFCC) and Support Vector Machines (SVM) method. In nternational Conference on Information and Communications Technology, ICOIACT 2018 (Vol. 18, pp. 935-940). https:// doi.org/10.1109/ICOIACT.2018.8350684

Mashuri, \& Dewi, M. (2017). Penerapan Metode Bernyanyi dan Media Flash Card untuk Meningkatkan Daya Ingat Anak dalam Pengenalan Huruf Hijaiyyah di TPA https://doi.org/10.22373/jm.v7i2.2368

Mohed, M. M., \& Ismail, S. (2015). Islamic Education Through Nature For Pre-School Children In Selangor And. Advances in Environmental Biology, 9(October), 129-147. 
Nastiti, N. A. (2015). TAHFIDZ Al-Qur'an Mempengaruhi Daya Ingat Anak di TK Islam Mardisiwi Pajang Laweyan Surakarta Tahun Ajaran 2014/2015 Artikel. Journal of applied microbiology.

Nurhayati, E. (2019). Literasi awal al-qur'an untuk anak usia dini dengan teknik reading aloud. Jurnal Pendidikan Anak, 5(1), 113-125. https://doi.org/10.24235/awlady.v5i1.3981

Nurwahyudi, R. (2018). Implementasi metode kibar dalam belajar membaca al-qur'an di Kelompok Roket TK IT Assalaam Pucanganom II Murtigading Sanden. Universitas Islam Negeri Sunan Kalijaga Yogyakarta.

Patterson, C. (2008). Child Development. New York: McGraw-Hill.

Prathiwi, S., \& Syamsudin, A. (2020). Iman dan karakter religius pada anak prasekolah $\begin{array}{lllll}\text { program tahfidz } \mathrm{di} \text { Indonesia. } & \text { JALIE, } 34 .\end{array}$ https://doi.org/http://dx.doi.org/10.33754/jalie.v4i01.205

Rifaatin, F. (2018). Analisis materi pembelajaran al-qur'an (studi perbandingan materi qiroati dan yanbu'a. IAIN Salatiga.

Safitri, E. M. (2011). Meningkatkan Kemampuan Melafalkan Surat Pendek melalui Media Audio dengan Teknik Murottal pada Anak Kelompok B TK Hasyim Asy"Ari Surabaya. Paud Teratai, 2(1), 1-5.

Sari, P., Fadillah, \& Lukmanulhakim. (2017). Pemanfaatan media audio visual dalam pengenalan huruf hijaiyah di TK Bina 45 II Pontianak. Jurnal Pendidikan Dan Pembelajaran, 6(10).

Schacter, D. L., \& Addis, D. R. (2007). Constructive memory: The ghosts of past and future. Nature, 445(7123), 27-27. https://doi.org/10.1038/445027a

Susianti, C. (2016). Efektivitas Metode Talaqqi dalam Meningkatkan Kemampuan Menghafal Al- Qur ' An Anak Usia Dini, 2(1). https://doi.org/10.22460/ts.v2i1p1-19.305

Vermala, H. T., Puspitaningrum, D., \& Setiawan, Y. (2016). Pengenalan pola huruf hijaiyah tulisan tangan menggunakan fuzzy feature extraction dan jaringan syaraf tiruan backpropagation. Jurnal Teknologi Informasi, 12(2), 172-180.

Vygotsky. (1978). Interaction between learning and development. New York: W.H. Freeman and Company.

Wahyuni, A., \& Syahid, A. (2019). Tren Program Tahfidz Al-Qur ' an sebagai Metode $\begin{array}{llll}\text { Pendidikan Anak. } & \text { 87-96. }\end{array}$ https://doi.org/10.32332/elementary.v5i1.1389

Widyawanti, E. (2016). Penerapan Metode Tilawati dalam Pembelajaran Membaca Al-Qur'an di Tk "Aisyiyah Bustanul Athfal VI Purwokerto. Institut Agama Islam Negeri Purwokerto. 